Lidia GAWLIK ${ }^{1}$

\title{
OPPORTUNITIES AND THREATS FOR HARD COAL MINING IN POLAND
}

\begin{abstract}
In the recent years, hard coal mining in Poland has been is in a deep crisis, which would have led to a number of bankruptcies if no countermeasures had been taken. The mentioned actions, though still insufficient, stabilized the situation. However, there is still a lot to do. Further steps, aimed at carrying out a radical reform of the hard coal mining and to build a profitable, efficient, and modern sector, are needed. In order to develop the strategy for the hard coal mining industry, a diagnosis of the present state and identification of the conditions in which it is functioning and will function in future is necessary. This can be done by analyzing the strengths and weaknesses of mining companies - taking into account internal conditions, as well as opportunities and threats - identified as objective, external conditions of the mining environment. There is a relative balance between the weak and strong sides of mining, but the biggest problem that needs to be solved is the high cost of production. The primary cause of the crisis, threatening the future development of the industry, is the situation in the world and domestic coal markets. The oversupply of coal and its low prices are the reasons for current production losses, menacing the viability of the industry. The fact that the majority owner of mining entities is the State (pursuing a favorable policy towards the industry, taking rescue actions, and introducing legal solutions for the sector) is a chance for a positive outcome. The rationale for such an attitude is the conviction that the energy security of Poland can be strengthened by the use of indigenous resources. In the long-term profit and loss account, further support for the sector, including tax reliefs, should be considered due to the fact that the potential liquidation of mining would not only result in high losses in the area of energy security, but would also bring negative social consequences, devastating effects on the mining region, and a loss of revenue for the state and local budgets.
\end{abstract}

Keywords: hard coal mining industry, strategic analysis, SWOT analysis, reforms.

\section{INTRODUCTION}

Coal has always been an important energy source in Poland. It was called black gold. During the bygone times of centrally planned economy, it was a source of foreign currency and the basic raw material which constituted the foundation of the country's development. Unfortunately, in the market economy (after the change of political system in Poland) the coal industry turned out to be unable to compete on the market. Hence, in the entire period since 1989, a continuous restructuring of the sector is taking place. In 2011 it seemed that the sector was in good shape, but unfortunately the situation deteriorated in subsequent years, and from 2013 on the financial results of coal mining are negative. Currently, the coal mining sector is in the next stage of restructuring, which is not an easy process.

1 D.Sc, Mineral and Energy Economy Research Institute, Polish Academy of Sciences, Wybickiego 7A, 31-261 Kraków; e-mail: lidia.gawlik@min-pan.krakow.pl. 
Before the official program for the hard coal mining sector was announced, intensive efforts aimed at saving a number of coal mines were already carried out. In the years 2015-2016, the Act of 7 September 2007 on the functioning of the hard coal mining industry in the years $2008-2015^{2}$ was amended five times. The January ${ }^{3}$ and December ${ }^{4} 2015$ amendments allowed extending financing of activities of SRK SA (Mine Restructuring Company) from budget subsidies, subsidizing production losses, extending the deadline for repayment of outstanding debts to the Social Insurance Institution (ZUS), and establishing the protective measures for employees of liquidated mines. The amendments made in 2016 (in February ${ }^{5}$, September ${ }^{6}$, and November ${ }^{7}$ ) were the basis for the implementation of organizational and ownership changes in mining entities, some of which were carried out.

Further steps, aimed at carrying out a radical reform of the hard coal mines and to build a profitable, efficient, and modern hard coal mining sector, are being planned.

The subject of this article is to analyze the present situation and to assess both internal and external conditions in which the mentioned renewal of the sector is planned.

\section{THE STATE OF HARD COAL MINING IN POLAND}

For many years, the global coal market is highly unstable. It is susceptible to structural changes in the energy markets, changes in market conditions, and global economic conditions. The characteristic feature of the coal market in the second decade of the 21 st century is the oversupply of this raw material and low prices on international markets. This problem has affected all coal producers in the world in recent years. The increase in production is accompanied by a decrease in demand, which is the consequence of slowing down the pace of development in countries that are the main users and importers of coal (this applies particularly to China, which experiences the slowest growth rate for more than two decades). As a result, the coal prices are currently lower than those observed between 2008 and 2009 during the global financial crisis ${ }^{8}$.

In 2015 , the worldwide coal production has dropped by $3.5 \%$ but was $6 \%$ higher than in 2010 , while the global steam coal trade has decreased by about $8 \%$. Coal prices have been on a downward trend for the fifth year in a row. In 2015 they decreased by $21 \%$ compared to the average of the previous year.

This has a major impact on the economic efficiency of Polish producers of this raw material. Since 2012, a rapid decrease in the demand for steam coal can be observed. In the

2 The Act of 7 September 2007 on functioning of hard coal mining in 2008-2015 (Journal of Laws, 2007 No. 192, item 1379, as amended).

3 The Act of 22 January 2015 on amending the act on the functioning of hard coal mining sector in the years 2008-2015 and some other acts (Journal of Laws, 2015, item 143).

4 The Act of 22 December 2015 on amending the act on the functioning of hard coal mining sector (Journal of Laws, 2015, item 2300).

5 The Act of 11 February 2016 amending the Government Administration Branches Act and certain other acts (Journal of Laws, 2016, item 266).

6 The Act of 14 September 2016 on amending the act on the functioning of hard coal mining sector and some other acts (Journal o Laws, 2016, item 1592).

7 The Act of 30 November 2016 on amending the act on the functioning of hard coal mining sector and some other acts (Journal o Laws, 2016, item 1991).

8 U. Lorenz, U. Ozga-Blaschke, The influence of changing market conditions on forecast prices of coal in international trade, "Przegląd Górniczy" 2016, No. 5, pp. 3-12. 
previous years, with improving financial results related to a rapid increase in the selling prices of coal mining companies, coal production costs have also increased (Fig. 1).

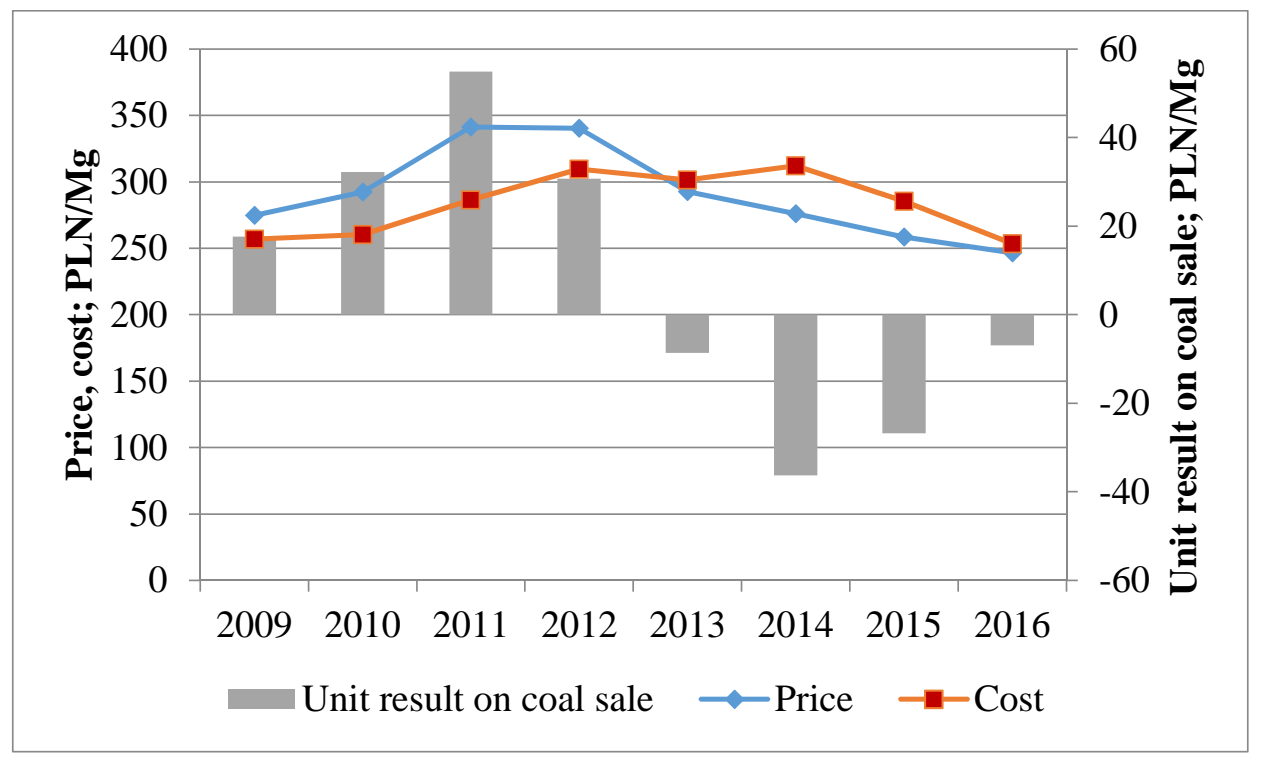

Fig. 1. Costs of hard coal production and coal prices in the years 2009-2016

Source: own work based on data from the Industrial Development Agency (ARP) 9 .

The increase in costs occurred also in the next years. This is a consequence of the increasing involvement of third parties carrying out mining services, higher costs of equipment, materials, increased lease or rental costs of mining machinery and equipment, as well as of the increase in labor costs resulting from excess employment. The coal sales in the industry started to drop sharply from nearly 55 PLN/tonne in 2011 to about 30.7 PLN/tonne in 2012, while in 2013 the negative accumulation (loss) of -8.56 PLN/tonne was reported. At the same time, a decrease in coal sales was observed, which further diminished the revenues from coal sales, while the production, not adjusted to market demand (that is too high), has contributed to the increase of coal stocks and, in addition, price reduction. The loss per tonne of coal sold, more than 36 PLN in 2014, put the Polish hard coal mining industry on the verge of bankruptcy. Emergency rescue measures, supported by anti-crisis acts and regulations (see above), organizational and ownership changes, and government decisions to finance the restructuring process from the state budget (state aid approved by the European Union) were introduced. In 2014 the Polish Mining Group (PGG) was established, which took over the mines with the potential for efficiency increase, firstly from the former Kompania Węglowa SA, and eventually also Katowicki Holding Węglowy SA. In 2015 , the increase in unit cost of coal sold was halted, but the result from coal sales, though

\footnotetext{
9 ARP. The Industrial Development Agency - online: https://katowice.arp.pl/o-nas (access on
} 31.05.2017). 
improved against the record-breaking year of 2014 (-2.2 billion PLN loss), remained negative (about -2 billion in 2015 and -0.5 billion in 2016) ${ }^{10}$.

The aim of further restructuring efforts is to achieve sustainable economic efficiency of the sector and to maintain rational use of the existing internal potential of coal mining: resources: geological, technical, and human. It is obvious that hard coal mining in Poland has the potential for development (strengths), but a number of features (weaknesses) limit the ability to effectively achieve goals and success.

\section{INTERNAL CONDITIONS AFFECTING THE FUNCTIO-NING OF HARD COAL MINING}

The main advantage of Polish coal mining industry is the abundance of hard coal resources while their use is seen as an element increasing the country's energy security. At the end of 2015, the balance resources in the currently exploited deposits amounted to 20.2 billion tonnes, while the economic (industrial) resources were 3.3 billion tonnes ${ }^{11}$. In addition, in 58 documented and currently undeveloped deposits, the balance resources amount to 31 billion tonnes ${ }^{12}$.

The amount of coal that can be extracted from the developed deposits, i.e. economic resources minus the losses, will last for another several decades of exploitation. It should be noted, however, that the size of the documented resources does not determine the possibility of coal production because:

- Some of them are located in mining protection areas such as pillars or under heavily urbanized areas, making it difficult or even technically impossible to extract coal,

- Substantial part of the resources is found in deposits with a thickness less than $1.5 \mathrm{~m}$ where mining activities require expensive exploitation systems,

- The amount of economic (industrial) resources and extractable resources in undeveloped deposits is not known,

- The majority of currently active coal mines have mining licenses valid until 2020. It should be noted that obtaining new or renewing the existing mining licenses is a lengthy and costly process. Hence, in the near future, unless preventive actions are taken, mines can face the unresolved formal and legal problems making it impossible to carry out mining activities.

In Poland, coal was mined already in the twenties of the previous century. After the Second World War, the development of coal mining has become one of the priorities of the country's economy. By 1980 a total of 18 new mines were built while the coal output continued to grow to reach the level of 200 million tonnes in the late seventies. Despite a slowdown in the pace of development, Poland has a significant technological potential associated with the production of coal, including modern coal exploitation and processing methods allowing customizing the product to the needs of the consumer. Strengths include technological know-how, countermeasures against natural hazards associated with the coal mining process in specific mining conditions, and the significant potential of human resources including both senior management and qualified employees. Coal sales companies

\section{${ }^{10}$ Ibidem}

${ }^{11}$ PIG-PIB, The balance of mineral resources deposits in Poland as of 31.12.2015. The Polish Geological Institute - National Research Institute. Warszawa 2016.

12 Ibidem. 
are also well developed and qualified. These include both own departments of the mining companies and a nationwide network of authorized resellers.

Weaknesses include the current unfavorable economic and financial situation, characterized by high losses, shortage of funds for current operations, low financial liquidity or lack thereof, and high liabilities. The profitability of the sector must be achieved and maintained under changing external conditions in order to carry out long term production of coal.

This is hampered by the conditions under which mining operations are conducted, resulting in difficulties in reducing costs and low decision-making flexibility in crisis situations, including:

- Weak organizational structures, especially in large companies consisting of many mines, resulting in delays in the flow of information and lengthening the decisionmaking process,

- Ineffective work organization systems limiting the degree of utilization of productive assets; the working time of machinery and equipment in many mines does not exceed $40 \%$ of the time of longwall availability, while longwall downtimes - for example after days off - make it difficult to carry out operating conditions due to the convergence of mine workings,

- Low flexibility in adjusting the production capacity to coal demand,

- Unfavorable employment structure and limited occupational mobility of employees,

- Low labor productivity,

- Ineffective remuneration systems, poorly linked to productivity,

- Low cost flexibility resulting from the high share of fixed costs (exceeding $80 \%$ of production costs in some of mines), the high level of costs associated with difficult geological and mining conditions (exploitation at deep depths or under natural hazards), and the impact of mining activities on the surface (mining damages).

Successful restructuring processes must be associated with overcoming or reducing of these weaknesses and lead to a reduction in excessive production costs. An additional difficulty is the overrepresentation of social side and its fragmentation. This makes the agreement between employees and employers more difficult.

The economic difficulties of mines that have occurred in the past few years have resulted in low levels of expenditures, including replacement investments. The limited level of financial resources spent on investments in relation to real investment needs worsens the operating conditions of mines, increases production costs, and leads to lower productivity. Time-consuming mining investment and high investment risk limit access to external sources of financing. Neglected investments and limited financial resources for development are the reason for the low innovativeness of the production, processing, and sales in the mining industry. Coal is produced and used primarily as a raw material for the production of electricity and heat. It should be noted, however, that the potential for innovation lies in the technology of coal gasification. Scientific studies and implementation attempts apply to both surface and underground gasification and may change the spectrum of use of this raw material.

Due to the long-term exploitation of large mining areas, a lot of mines have a very extensive underground structure, long underground transport system, and carry out sublevel mining. In the case of mines with rich deposits, modernizations and expenditures for better and more optimal access to these raw materials are needed. The solution could be technical integration of individual mines into complex mines. Such actions are possible because the 
mining areas are located close to each other, and since the majority owner of almost all mining enterprises is the State. In spite of theories that public enterprises have proved to be less efficient than the privatized ones ${ }^{13},{ }^{14}$ in this case the public enterprises could be restructured using the strategies prepared and implemented on a scale that goes beyond one company.

An analysis of internal factors affecting the development of hard coal mining, presented and summarized in Table 1, does not show the advantage of strengths over weaknesses

Table 1. Internal conditions affecting the state of hard coal mining in Poland

\begin{tabular}{|c|c|}
\hline Strengths & Weaknesses \\
\hline Large balance resources of hard coal; & $\begin{array}{l}\text { Depleting operational resources; } \\
\text { Ending concessions for mining activities; }\end{array}$ \\
\hline $\begin{array}{l}\text { Comprehensive management of the entire } \\
\text { production and sales process; } \\
\text { High storage capacity and efficient material } \\
\text { logistics; }\end{array}$ & $\begin{array}{l}\text { Ineffective organizational structures resulting in } \\
\text { lengthening decision-making processes and low } \\
\text { efficiency of information flow; }\end{array}$ \\
\hline $\begin{array}{l}\text { High technological potential; } \\
\text { High degree of longwall mechanization; }\end{array}$ & Low utilization of the potential of the machinery; \\
\hline $\begin{array}{l}\text { Proper identification of natural hazards and } \\
\text { effective countermeasures; }\end{array}$ & $\begin{array}{l}\text { Difficult mining and geological conditions in } \\
\text { mines; }\end{array}$ \\
\hline $\begin{array}{l}\text { Proper analysis of the domestic market of } \\
\text { consumers; } \\
\text { Wide assortment of offered products; }\end{array}$ & $\begin{array}{l}\text { Limited efforts to adjust the production capacity to } \\
\text { coal demand; }\end{array}$ \\
\hline Developed network of authorized sellers; & $\begin{array}{l}\text { No stable coal distribution network for house- } \\
\text { holds; }\end{array}$ \\
\hline $\begin{array}{l}\text { The high level of post-mining waste manage- } \\
\text { ment in the underground workings of mines; }\end{array}$ & $\begin{array}{l}\text { Production process with a negative impact on the } \\
\text { environment; }\end{array}$ \\
\hline High potential for coal processing; & $\begin{array}{l}\text { Low innovativeness of the production, processing } \\
\text { and sales of coal; }\end{array}$ \\
\hline Experience and qualifications of employees; & $\begin{array}{l}\text { Unfavorable employment structure and limited oc- } \\
\text { cupational mobility of employees, including the } \\
\text { internal mobility; }\end{array}$ \\
\hline $\begin{array}{l}\text { The willingness and commitment of the } \\
\text { social partners to cooperate in solving } \\
\text { problems related to the implementation } \\
\text { of employment policy; }\end{array}$ & $\begin{array}{l}\text { Low optimization of work systems, resulting in, } \\
\text { among others, insufficient efficiency of working } \\
\text { time and remuneration systems that are not } \\
\text { motivating for increased productivity; }\end{array}$ \\
\hline $\begin{array}{l}\text { Possibility of applying various solutions to } \\
\text { individual mines, including their technical } \\
\text { integration into multi-branch enterprises; }\end{array}$ & $\begin{array}{l}\text { The need to modernize and incur high costs of } \\
\text { excavation works in some of mines, in which coal } \\
\text { deposits are abundant and coal is commercially } \\
\text { attractive; }\end{array}$ \\
\hline $\begin{array}{l}\text { One majority owner (direct or indirect) of } \\
\text { all entities in the hard coal mining sector. }\end{array}$ & $\begin{array}{l}\text { Critical economic and financial situation of mining } \\
\text { companies; } \\
\text { Lack of investment funds; }\end{array}$ \\
\hline
\end{tabular}

Source: own elaboration.

${ }^{13}$ M. Boycko, A. Shleifer, R.W. Vishny, A Theory of Privatisation, "The Economic Journal" 1996, 106(435), pp. 309-319.

${ }^{14}$ Z. Liu, The Comparative Performance of Public and Private Enterprises: The Case of British Ports, "Journal of Transport Economics and Policy" 1995, 29(3), pp. 263-274. 
of the sector. The identified weaknesses of coal mining can be eliminated, but this requires certain investments and therefore is associated with a corresponding and adequate decisionmaking process.

\section{EXTERNAL FACTORS AFFECTING HARD COAL MINING}

The current coal mining crisis is mainly due to external factors, on which the Polish mining industry, under the conditions of international competition, has no influence.

The functioning of the hard coal mining industry in Poland largely depends on the situation of available energy carriers on the domestic and global markets ${ }^{15}$.

A characteristic feature is the high dependence of the domestic coal market on the situation on the global markets of coal and other energy resources, which is not good. There is a surplus of coal on the global market. Also in Poland the supply exceeds demand. Due to the fact that the production volume was not adjusted to the current sales, 8.2 million tonnes of coal were deposited in dumping grounds at the end of 2014. In 2015, coal stocks decreased to 5.2 million tonnes but the sale of coal from the dumping grounds has contributed to a significant reduction in the average price of coal by over $6 \%^{16}$.

The prices of steam coal on the world markets have stabilized at a low level. Moreover, forecasts for the coming years do not predict their growth due to overcapacity in the world and the declining demand. Although in the second half of 2016 an upward trend in the price of steam and coking coal was observed, the forecasts are not favorable and hard coal prices will remain low at least until 2020. In the long run, no significant increase in coal prices is expected ${ }^{17}$. This means that achieving the profitability of Polish coal mining will require a significant reduction in coal production costs. The low USD exchange rate against PLN is an another factor deteriorating the competitiveness of Polish coal on the domestic market in relation to imported (especially from the East) coal.

Poland has become an importer of coal. Since 2008, coal imports surpassed coal exports, thus reducing the domestic market. At the same time coal exports have declined. Polish producers have lost their markets abroad and due to the appearance of new, previously marginal importers on the European market, returning to these markets will be difficult.

Another important factor for the future of coal mining in Poland is the EU climate policy. Within the framework of climate and energy policy until 2030, The EU is pursuing three key targets: at least 40\% cut in greenhouse gas emissions (compared to 1990 levels), at least $27 \%$ of total energy consumption from renewable energy, and at least $27 \%$ increase in energy efficiency. The framework was adopted by EU leaders in October 2014. It builds on the 2020 climate and energy package ${ }^{18}$. It is also in line with the longer term perspective

\footnotetext{
15 J. Dubiński, M. Turek, Szanse i zagrożenia rozwoju górnictwa węgla kamiennego w Polsce, „Wiadomości Górnicze" 2012, No. 11, pp. 625-633.

16 ARP 2015. The Industrial Development Agency, 2015. The Industrial Development Agency. Katowice Branch, data processed on the basis of the results of the survey of public statistics by the Minister of Economy "Coal mining", executed by ARP SA, Katowice Branch.

17 IEA 2016. Coal. Medium Term Market Report 2016. Market Analysis and Forecast to 2021. International Energy Agency, Paris.

${ }^{18}$ European Commission, EU climate action. European Commission [online] https://ec.europa.eu/clima/policies/strategies/2030_pl access on 23.06.2017.
} 
set out in the Roadmap for moving to a competitive low carbon economy in $2050^{19}$, the Energy Roadmap $2050^{20}$, and the Transport White Paper ${ }^{21}$.

The consistently implemented EU policy towards reducing greenhouse gas emissions is targeted at fossil fuels, especially solid fuels (hard coal and lignite), as those associated with high emissions. In the so-called "Winter Package" 22 of the European Commission proposes changes to reorganize the electricity market, revisions to the Renewable Energy Directive and Energy Efficiency, and a $\mathrm{CO}_{2}$ limit of 550 grams of $\mathrm{CO}_{2}$ per kilowatt hour for power plants, which would exclude coal-fired power stations from CAT mechanism eligibility.

The prospects for the development of coal market are unfavorable due to the increasing competitiveness of other energy carriers on both domestic and foreign electricity markets, which is further stimulated by falling oil and gas prices and the growing use of renewable energy sources. With growing pollution, there is growing social opposition against the so-called low stack emissions produced as a result of, among others, burning of coal for heating purposes. The tightening of environmental standards is slowly becoming a fact, and this means that an increase in $\mathrm{CO}_{2}$ emission charges is expected, which will affect coal power industry while the use of coal for household purposes will be limited by local resolutions and national laws. It is estimated $^{23}$ that the demand for hard coal in Poland in 2030 may be $20 \%$ lower than in 2015 unless measures to reverse this trend are taken.

Another factor impeding the development of the mining industry is the seasonal demand for coal, with a peak in the winter season, and the lack of instruments to mitigate the negative effects. Adapting the production to such sales conditions requires complex activities in the area of production management and logistics (product storage and sales).

In addition to market factors, there are difficulties with access to the existing and documented, yet undeveloped, deposits. There are no legal solutions to secure these deposits as strategic and to introduce surface development restrictions. This makes the access to the deposits and their future exploitation difficult or even impossible. Local Spatial Management Plans, which do not take into account the existence of deposits, lengthen the process of opening up coal deposits. The lengthy and costly licensing process is another obstacle. Therefore, it may soon become apparent that there will be not enough reserves for the preparation of new exploitation fronts.

${ }^{19}$ European Commission 2011. A Roadmap for moving to a competitive low carbon economy in 2050. Communication From The Commission To The European Parliament, The Council, The European Economic And Social Committee And The Committee Of The Regions. COM(2011) 112 final, European Commission, Brussels, 8.3.2011. [online] http://www.europarl.europa.eu/meetdocs/2009_2014/documents/com/com_com(2011)0112_/com_com(2011)0112_pl.pdf access on 23.06.2017.

${ }^{20}$ European Parliament resolution of 14 March 2013 on the Energy roadmap 2050, a future with energy $(2012 / 2103($ INI)). OJ C 36, 29.1.2016, pp. 62-76 [online] http://eur-lex.europa.eu/legalcontent/PL/TXT/?uri=CELEX\%3A52013IP0088 access on 23.06.2017.

${ }^{21}$ White Paper. Roadmap to a Single European Transport Area - Towards a competitive and resource efficient transport system. COM/2011/0144 final. European Commission, Brussels, 28.3.2011 [online] http://eur-lex.europa.eu/legal-content/PL/TXT/PDF/?uri=CELEX:52011DC0144\&from= $=\mathrm{PL}$ access on 23.06.2017.

${ }^{22}$ Clean Energy for All Europeans - unlocking Europe's growth potential. European Commission Press release Brussels, 30 November 2016.

${ }^{23}$ The Ministry of Development, Program for the bituminous coal mining sector in Poland (draft), Warsaw, February 2017. 
A significant consolidation of the suppliers for hard coal industry results in higher costs of materials, services, machines, and equipment, which translates into higher production costs in mining industry. On the revenue side, the threat is a strong position of power sector when negotiating coal prices and, when it comes to coal shipment, a high degree of dependence on a single transport provider.

Table 2. The structure of electricity production in domestic power plants, the volume of electricity exchange with foreign countries, and the energy consumption in Poland in 2015 and 2016, GWh

\begin{tabular}{|c|l|c|c|c|}
\hline No. & Item & 2015 & 2016 & Dynamics \\
\hline 1 & Total production & 161772 & 162626 & 0.53 \\
\hline 1.1 & Professional power plants & 141901 & 140727 & -0.83 \\
\hline 1.1 .1 & Professional hydropower plants & 2261 & 2399 & 6.10 \\
\hline 1.1 .2 & Professional thermal power plants & 139640 & 138328 & -0.94 \\
\hline 1.1 .2 .1 & Hard coal power plants & 81883 & 81348 & -0.65 \\
\hline 1.1 .2 .2 & Lignite power plants & 53564 & 51204 & -4.41 \\
\hline 1.1 .2 .3 & Gas power plants & 4193 & 5776 & 37.75 \\
\hline 1.2 & Other renewable power plants & 73 & 146 & 100.00 \\
\hline 1.3 & Wind power & 10041 & 11623 & 15.76 \\
\hline 1.4 & Industrial power plants & 9757 & 10130 & 3.82 \\
\hline 2 & The foreign exchange balance & -334 & 1999 & - \\
\hline 3 & The domestic electricity consumption & 161438 & 164625 & 1.97 \\
\hline
\end{tabular}

Source: PSE $2016^{24}$.

Fossil energy resources: petroleum, natural gas, and coal currently have no substitutes able to meet the current energy demand ${ }^{25}$. To some extent, nuclear energy can be used as alternative energy source; however, there are psychological objections to its use and, what is more, not all technological problems of the fourth generation reactors ${ }^{26}$, nor the problems of safe disposal of radioactive waste generated in the production and processing of nuclear fuel have been solved yet ${ }^{27}$. The fact that there is no alternative to meet the energy needs of the country is a fundamental opportunity for the mining industry.

Polish energy sector is based on solid fuels. The share of hard coal in electricity production, despite a downward trend, is over $50 \%$ while the domestic electricity consumption tends to increase (Table 2).

The high primary energy dependence on coal, including electricity and heat, means that, in the medium-term, coal will remain the primary raw material for the production of electricity in Poland, although attention should be paid to the lack of investment (or excessive delays in their implementation) in the coal-fired power sector.

${ }^{24}$ PSE 2016. Polskie Sieci Elektroenergetyczne SA. [online] http://www.pse.pl/index.php?modul=8\&y=2015\&m=12\&id_rap=212 access on 20.06.2017.

25 J. Dubiński, M. Turek, Szanse i zagrożenia...

${ }^{26}$ E. Mokrzycki, R. Ney, J. Siemek, Global reserves of energy fossil resources - conclusions for Poland, "Energy market" 2008, No. 6 p. 3.

${ }^{27}$ K. Probierz, Polish coal mining in 2015 - opportunities and threats, "Przegląd Górniczy" 2015, No. 4, pp. 22-37. 
The development of renewable energy is a source of instability in the power system. The existing coal-fired power plants could be used as peak power sources to maintain an adequate power volume of the power system, which would ensure the demand for hard coal.

The growing popularity of Low Emission Reduction Programmes reduces the demand for coal and its substitution with other household energy carriers, but the dynamic development of the building industry, including areas beyond access to gas networks, provides an opportunity to increase the demand for steam coal for low-power household boilers. Another favorable factor is the ability to adapt commercial products to the market needs. There are opportunities, knowledge, and technologies to increase the production of qualified coal fuels that are feasible for efficient use in low emission boilers. The cooperation of coal producers with the producers and sellers of these boilers combined with the strong research base of the sector are prerequisites for the development of market for this coal.

The biggest opportunity for mining, which allows an optimistic look at the future of the industry, is a favorable government policy. The rationale for such an attitude is the conviction that the energy security of Poland can be strengthened by the use of indigenous resources.

Poland, without significant oil reserves and with more than $70 \%$ of its domestic demand for natural gas met by imports, is one of the least energy-dependent countries in the European Union thanks to the abundance of solid fuels (hard coal and lignite). In 2014, Poland's import dependency ratio was $28.6 \%$, putting it in fourth place among the countries least dependent on the imported energy, followed by Estonia (8.9\%), Denmark (12.8\%) and Romania (17.0\%). Meanwhile, the average European Union dependence on energy imports amounted to $53.5 \%$. Maintaining this relatively high energy independence is particularly important in the Polish geopolitical situation on the eastern flank of the European Union, with Russia being the largest importer of energy resources and under the conditions of hindered diversification of oil and gas supplies.

The number of people employed in coal mining is also of great importance. By the end of 2015, more than 92.000 peoples were employed in the bituminous coal mining sector ${ }^{29}$. Due to the fact the vast majority of mines are located in the Upper Silesian Coal Basin, the possible liquidation of mining activities would contribute to social problems in the region.

\section{CONCLUDING REMARKS}

The presented diagnosis of the mining industry and its external surroundings is aimed at gathering information and identifying the factors that determine its development potential. These data are collected in the course of strategic analysis dedicated to companies trying to overcome crisis or difficult situations ${ }^{30}$. Their identification and evaluation is essential for developing a strategy for the future, because overcoming the crisis, renewal, and effective functioning can be achieved by taking advantage of the strengths and opportunities in the environment and by avoiding risks and strengthening weaknesses.

\footnotetext{
${ }^{28}$ EU 2016. Energy, transport and environment indicators. 2016 edition. European Union, Luxemburg.

${ }^{29}$ H. Paszcza, Górnictwo węgla kamiennego w liczbach. Materiały Szkoły Eksploatacji Podziemnej, Kraków 25.02.2016.

${ }^{30}$ G. Gierszewska, M. Romanowska, Analiza strategiczna przedsiębiorstwa, Warszawa 2009.
} 
Internal factors can be, to some extent, modified by management decisions, although overcoming weaknesses (or only strengthening them) is usually associated with the need to incur expenditure on process changes, technological base, work organization, or adaptation to the environment and prevailing conditions ${ }^{31}$.

The source of failure of strategic operations may be due to external negative processes, phenomena, and trends in the business environment, which constitute or may constitute a barrier to the development of the mining industry, hindering its functioning, increasing operating costs and, consequently, leading to collapse. These hazards are difficult to mitigate as they are not dependent on the internal decisions of the industry. Overcoming them will depend on strengthening the weaknesses of coal mining and on the dominance of opportunities over threats. Hard coal mining industry is taking a number of measures to reorganize the structure of the sector; some mines, considered to be permanently unprofitable, are being closed, while there are ongoing efforts on reducing production costs.

The main problem is the lack of funds for investments, including the development of exploitation fronts and preparatory works. The fact that the State is taking rescue actions and is introducing legal solutions for the hard coal mining sector is a chance for a positive outcome. The strategic decisions taken at the government level are associated with the determination to effectively use the resource, social, and economic capital of the coal mining industry while paying attention to energy independence of the country and supporting the competitiveness of the national economy. An important element of the action program for the coming years is to define the role of coal in the structure of electricity production. Poland cannot move away from coal-based power generation; the processes of capital integration (vertical integration) between hard coal producers and the energy sector is the expression of this approach.

After the organizational and capital changes made in the last year, the mining industry operates in a completely different structure. A relative stabilization of the economic situation can be observed. However, there is a need for actions aimed at increasing the competitiveness and innovativeness of mining, including a number of $\mathrm{R} \& \mathrm{D}$ works.

Between other measures, that could help the industry to achieve the new equilibrium, the possibility of temporary co-financing of mining activities, also in the form of special tax relief, should be considered. This conclusion is a result of the profit and loss account, that takes into consideration all the consequences of the possible liquidation of Polish coal mining, including: negative social consequences (a loss of jobs in the mining sector and other jobs generated by the industry), devastating effects on civilization (environmental degradation of mining areas and lack of development opportunities for Silesians), adverse fiscal consequences (the loss of public revenue that is currently generated by the mining companies and enterprises operating within the mining industry), and the negative impact on national security (increased dependence on imported energy carriers).

\section{REFERENCES}

[1] Act of 7 September 2007 on functioning of hard coal mining in 2008-2015 (Journal of Laws, 2007 No. 192, item 1379, as amended).

[2] Act of 22 January 2015 on amending the act on the functioning of hard coal mining sector in the years 2008-2015 and some other acts (Journal of Laws, 2015, item 143).

\footnotetext{
${ }^{31}$ J. Dubiński, M. Turek, Szanse i zagrożenia...
} 
[3] Act of 22 December 2015 on amending the act on the functioning of hard coal mining sector (Journal of Laws, 2015, item 2300).

[4] Act of 11 February 2016 amending the Government Administration Branches Act and certain other acts (Journal of Laws, 2016, item 266).

[5] Act of 14 September 2016 on amending the act on the functioning of hard coal mining sector and some other acts (Journal o Laws, 2016, item 1592).

[6] Act of 30 November 2016 on amending the act on the functioning of hard coal mining sector and some other acts (Journal o Laws, 2016, item 1991).

[7] ARP. Industrial Development Agency - online: https://katowice.arp.pl/o-nas (access on 31.05.2017).

[8] ARP, 2015. The Industrial Development Agency, 2015. The Industrial Development Agency. Katowice Branch, data processed on the basis of the results of the survey of public statistics by the Minister of Economy "Coal mining", executed by ARP SA, Katowice Branch.

[9] Boycko M., Shleifer A., Vishny R.W., Theory of Privatisation, "The Economic Journal" 1996, 106(435), pp. 309-319.

[10] Clean Energy for All Europeans - unlocking Europe's growth potential. European Commission - Press release Brussels, 30 November 2016.

[11] Dubiński J., Turek M., Szanse i zagrożenia rozwoju górnictwa węgla kamiennego w Polsce, „Wiadomości Górnicze” 2012, No. 11, pp. 625-633.

[12] EC. European Commission, EU climate action. European Commission [online] https://ec.europa.eu/clima/policies/strategies/2030_pl access on 23.06.2017.

[13] EC 2011. European Commission 2011. A Roadmap for moving to a competitive low carbon economy in 2050. Communication From The Commission To The European Parliament, The Council, The European Economic And Social Committee And The Committee Of The Regions. COM(2011) 112 final, European Commission, Brussels, 8.3.2011 [online] http://www.europarl.europa.eu/meetdocs/2009_2014/documents/com/com_com(2011)0112 _/com_com(2011)0112_pl.pdf access on 23.06.2017.

[14] Energy, transport and environment indicators. 2016 edition. European Union, Luxemburg.

[15] EP, 2013. European Parliament resolution of 14 March 2013 on the Energy roadmap 2050, a future with energy (2012/2103(INI)). OJ C 36, 29.1.2016, pp. 62-76 [online] http://eurlex.europa.eu/legal-content/PL/TXT/?uri=CELEX\%3A52013IP0088 access on 23.06.2017.

[16] Gierszewska G., Romanowska M., Analiza strategiczna przedsiębiorstwa (Strategic analysis of the enterprise), Polskie Wydawnictwo Ekonomiczne, Warszawa 2009.

[17] IEA 2016. Coal. Medium Term Market Report. Market Analysis and Forecast to 2021. International Energy Agency, Paris 2016.

[18] Liu Z., The Comparative performance of Public and private Enterprises: The case of British Ports, "Journal of Transport Economics and Policy" 1995, 29(3), pp. 263-274.

[19] Lorenz U., Ozga-Blaschke U., The influence of changing market conditions on forecast prices of coal in international trade, "Przegląd Górniczy 2016, No. 5, ZG SITG Katowice, pp. 3-12.

[20] Ministry of Development, Program for the bituminous coal mining sector in Poland (draft), Warsaw, February 2017.

[21] Mokrzycki E., Ney R., Siemek J., Global reserves of energy fossil resources - conclusions for Poland, "Rynek Energii" 2008, No. 6 p. 3.

[22] Paszcza H., Górnictwo węgla kamiennego w liczbach. Materiały Szkoły Eksploatacji Podziemnej, Kraków 25.02.2016. 
[23] PIG-PIB, The balance of mineral resources deposits in Poland as of 31.12.2015. The Polish Geological Institute - National Research Institute. Warszawa 2016.

[24] Probierz K., Polish coal mining in 2015 - opportunities and threats, "Przegląd Górniczy" 2015, No. 4, pp. 22-37.

[25] PSE 2016. Polskie Sieci Elektroenergetyczne SA. [online] http://www.pse.pl/index.php? modul $=8 \& y=2015 \& m=12 \& i d \_r a p=212$ access on 20.06.2017.

[26] White Paper. Roadmap to a Single European Transport Area - Towards a competitive and resource efficient transport system. /COM/2011/0144 final, European Commission, Brussels, 28.3.2011 [online] http://eur-lex.europa.eu/legal-content/PL/TXT/PDF/?uri=CELEX: 52011DC0144\&from=PL access on 23.06.2017.

\section{SZANSE I ZAGROŻENIA DLA GÓRNICTWA WĘGLA KAMIENNEGO W POLSCE}

Górnictwo węgla kamiennego w ostatnich kilku latach jest w kryzysowej sytuacji, która bez podjęcia działań ratunkowych, mogła doprowadzić wiele jego podmiotów do bankructwa. Podjęte kroki, choć wciąż niewystraczające, ustabilizowały nieco sytuację. Jest jednak jeszcze bardzo wiele do zrobienia. Potrzebne są dalsze działania, których celem ma być budowa rentownego, efektywnego i nowoczesnego sektora górnictwa węgla kamiennego. Aby zbudować strategię górnictwa węgla kamiennego na przeszłość potrzebna jest diagnoza stanu obecnego oraz identyfikacja uwarunkowań jego funkcjonowania. Służy temu przeprowadzona analiza mocnych i słabych stron przedsiębiorstw górniczych - uwzgledniająca wewnętrzne warunki działalności oraz szans i zagrożeń, identyfikowanych jako obiektywnie występujące warunki w otoczeniu górnictwa. Pomiędzy słabymi i mocnymi stronami górnictwa istnieje względna równowaga, jednak największym problemem, który wymaga interwencji jest wysoki koszt produkcji. Podstawową przyczyną kryzysu oraz zagrożeniem dla przyszłego rozwoju jest sytuacja na rynku węgla, przede wszystkim światowym, ale również krajowym. Nadpodaż węgla i niskie jego ceny są powodem ponoszonych strat na bieżącej produkcji, co zagraża długoterminowej efektywności funkcjonowania. Szansę na pozytywne rozwiązanie stanowi fakt, że większościowym właścicielem podmiotów górnictwa jest Państwo, które reprezentuje postawę sprzyjającą, prowadząc działania interwencyjne i wprowadzając sektorowe rozwiązania prawne. Przesłanką dla takiej postawy jest przeświadczenie, że bezpieczeństwo energetyczne kraju może być wzmocnione poprzez wykorzystanie rodzimych zasobów. W długoterminowym rachunku zysków i strat, należy rozważać dalsze wsparcie dla sektora, w tym również ulgi podatkowe, bo ewentualna likwidacja sektora wiązałaby się z wysokimi stratami nie tylko w obszarze bezpieczeństwa energetycznego, ale również przyniosłaby negatywne skutki społeczne, cywilizacyjne i ubytek dochodów dla budżetu państwa i budżetów lokalnych.

Słowa kluczowe: górnictwo węgla kamiennego, analiza strategiczna, analiza SWOT, reforma.

DOI:10.7862/rz.2017.hss.20

Przestano do redakcji: luty $2017 \mathrm{r}$.

Przyjęto do druku: czerwiec 2017 r. 
